Research Article

\title{
Synthesis and Evaluation of Antimicrobial Activities of Novel N-Substituted Indole Derivatives
}

\author{
Tanveer MahamadAlli Shaikh (D) and Habtamu Debebe \\ Department of Chemistry, College of Natural and Computational Sciences, Mekelle University, Mekelle, Ethiopia \\ Correspondence should be addressed to Tanveer MahamadAlli Shaikh; tanveerchem1@gmail.com
}

Received 28 June 2019; Accepted 20 March 2020; Published 14 April 2020

Guest Editor: Maria Grazia Bonomo

Copyright (c) 2020 Tanveer MahamadAlli Shaikh and Habtamu Debebe. This is an open access article distributed under the Creative Commons Attribution License, which permits unrestricted use, distribution, and reproduction in any medium, provided the original work is properly cited.

Indole motifs are one of the most significant scaffolds in the discovery of new drugs. We have described a synthesis of new $\mathrm{N}$-substituted indole derivatives (1-3), and their in vitro antimicrobial activities were investigated. The synthesis of titled compounds has been demonstrated by utilizing commercially available starting materials. The antibacterial and antifungal activities were performed using new strains of bacteria Staphylococcus aureus, Escherichia coli, and Candida albicans using the disc diffusion method. Notably, the compound 4-(1-(2-(1H-indol-1-yl) ethoxy) pentyl)-N,N-dimethyl aniline (1) was found to be most potent than the other analogues (2 and 3$)$, which has shown higher inhibition than the standard drug chloramphenicol.

\section{Introduction}

The versatility of heterocycles has been known from the century since their direct involvement in natural products [1-4]. Particularly, the nitrogen-containing heterocycles (Nheterocycles) have proven ubiquitous structural features and pivotal role in medicinal chemistry [5-11]. Amongst the various $\mathrm{N}$-heterocycles, indole motifs have received significant attention due to their presence in proteins, amino acids, bioactive alkaloids, and drugs (Figure 1) [12-23]. In this context, a large number of indole moieties have been investigated in the development of new efficient bioactive molecules with diverse pharmacological properties, such as antimicrobial, antiviral, anticancer, anti-inflammatory, inhibitors, and antioxidant [24-47]. Generally, indoles substituted at $2^{\text {nd }}$ or $3^{\text {rd }}$ position [48-50], are known to exhibit certain bioactivity. On the other hand, the importance of N1-substituted indole derivatives in marketed drug molecules, natural products, and marine organisms are at great extent [51-53]. Despite the structural novelties and valuable biological activities of N1-substituted indoles [54], it remains challenging due to the inertness of the nitrogen atom (-NH-) towards electrophilic reagents [55-61].
A literature survey reveals that the infections caused by bacteria, fungi, or microorganisms in tropical and subtropical regions could be controlled by designing new antimicrobial agents $[62,63]$. In an attempt to design and synthesize new antimicrobial agents, herein, we reported the synthesis of N1-alkylated indole derivatives and investigation of their antimicrobial activity against Staphylococcus aureus, Escherichia coli, and Candida albicans (Figure 2).

\section{Results and Discussion}

As part of our studies to design new bioactive $\mathrm{N}$-substituted indole derivatives, we envisaged that the utilization of commercially available 4-N,N-dimethylamino benzaldehyde might be suitable for the syntheses of target compounds 1-3. The retrosynthetic analyses of $\mathrm{N}$-substituted indoles (1-3) are outlined in Scheme 1. In order to find suitable synthons, firstly, the cleavage of $\mathrm{C}-\mathrm{O}$ bond resulted to $\mathrm{N}$-alkylated indole 7 and the corresponding benzylic alcohols 4-6, which could be envisaged to form desired compounds (1-3) via $\mathrm{O}$-alkylation reaction. Furthermore, a common intermediate 7 could be synthesized via $\mathrm{N}$-alkylation reaction of commercially available indole (9) and 1,2-dibromoethane 
<smiles>Oc1ccc2c(c1)C(CCCN1CCC(c3ccccc3)CC1)CN2</smiles>

(a)

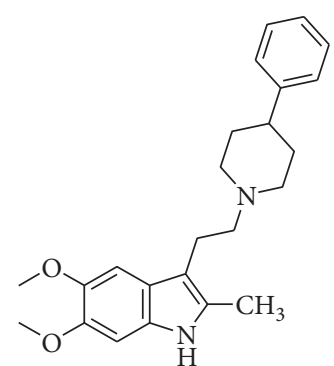

(b)<smiles>CC(C)NCC(O)COc1cccc2[nH]ccc12</smiles>

(c)<smiles>COc1ccc2c(c1)c(CC(=O)O)c(C)n2C(=O)c1ccc(Cl)cc1</smiles>

(d)

Figure 1: Representative examples of drugs with indole. (a) Roxindole schizophrenia. (b) Oxypertine antipsychotic drug. (c) Pindolol antihypertensive drug. (d) Indometacin anti-inflammatory drug.<smiles>CCCCC(OCCn1ccc2ccccc21)c1ccc(N(C)C)cc1</smiles>

1<smiles>CCC(OCCn1ccc2ccccc21)c1ccc(N(C)C)cc1</smiles>

2<smiles>CN(C)c1ccc(C(OCCn2ccc3ccccc32)c2ccccc2)cc1</smiles>

3

Figure 2: New bioactive indole derivatives.

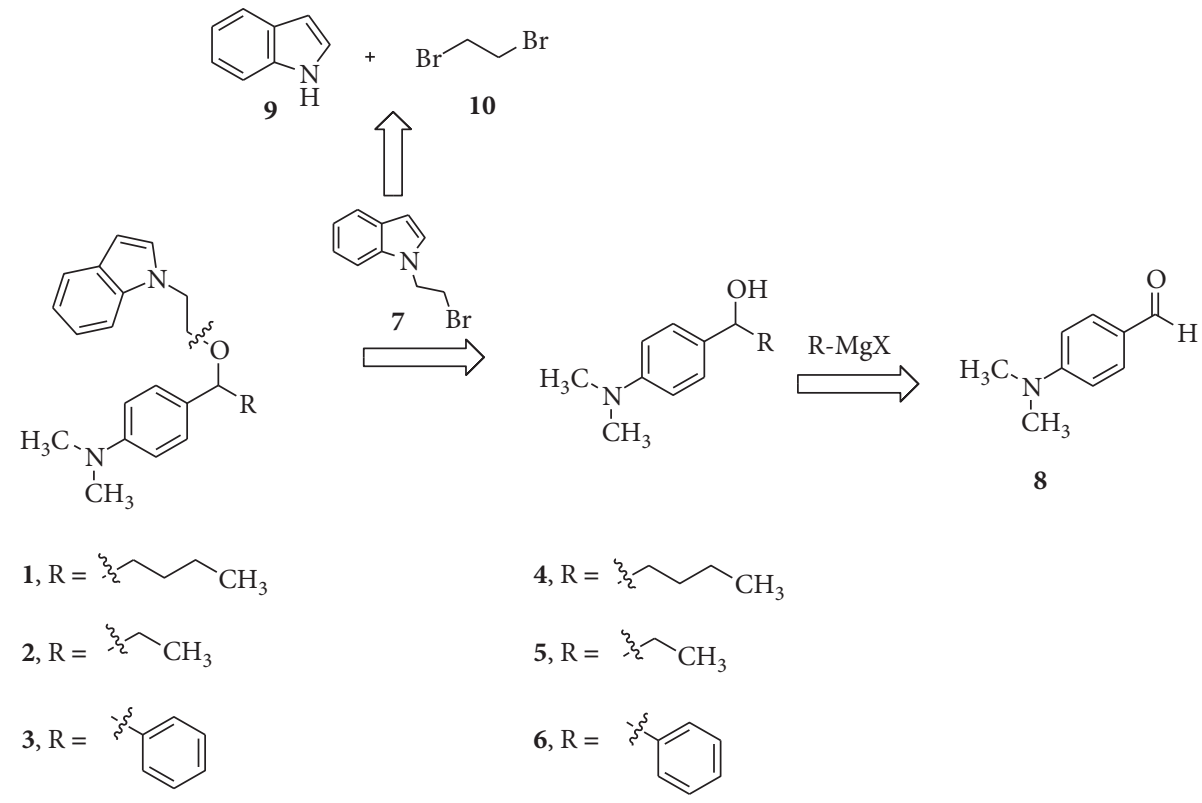

Scheme 1: Retrosynthesis of compounds 1-3.

(10). Finally, the benzylic alcohols 4-6 could be obtained by performing Grignard reaction of 4-N,N-dimethylamino benzaldehyde (8) with the corresponding alkyl or aryl halide.

To validate our outlined approach, we have commenced our synthesis by performing Grignard reaction of $4-\mathrm{N}, \mathrm{N}-$ dimethylamino benzaldehyde (8) with $n-\mathrm{BuMgBr}$, which was prepared by in situ reaction of $n-\mathrm{BuBr}(\mathbf{1 0})$ and $\mathrm{Mg}$ in diethyl ether solvent resulting in benzylic alcohol $\mathbf{4}$ at an excellent yield (Scheme 2). Similarly, the other benzylic alcohols $\mathbf{5}$ and $\mathbf{6}$ were successfully obtained by subjecting "Grignard reaction" of 4-N,N-dimethylamino benzaldehyde (8) with EtMgBr and $\mathrm{PhMgBr}$, respectively. Next, we investigated the synthesis of $\mathrm{N}$-alkyl indole (7) via $\mathrm{N}$-alkylation, employing commercially available indole (9) with 1,2-dibromoethane (13) in the presence of potassium hydroxide as base and DMF as a solvent (Scheme 3) [64]. In 

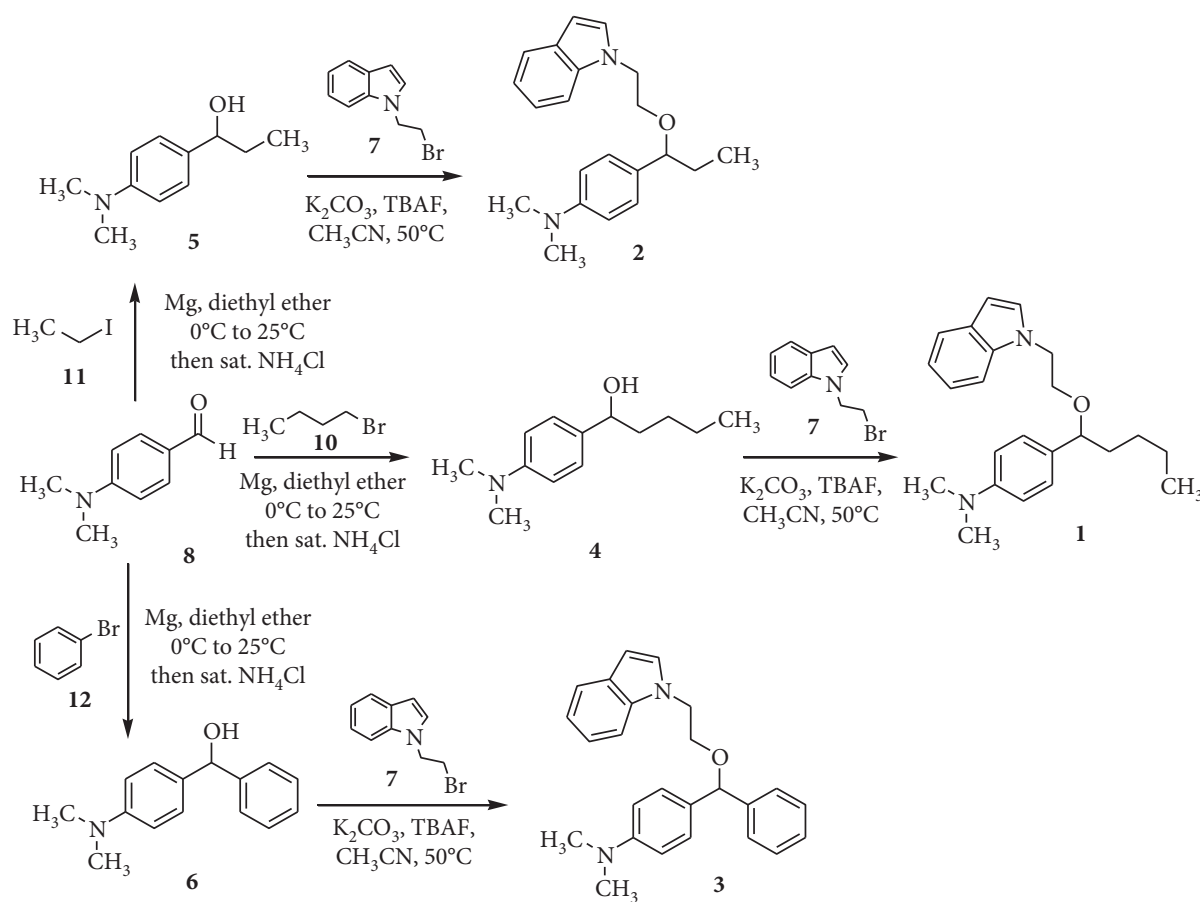

4

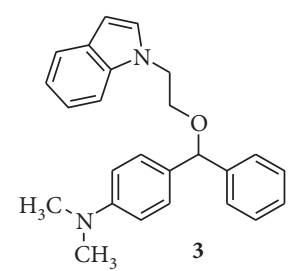

Scheme 2: Synthesis of target compounds 1-3.
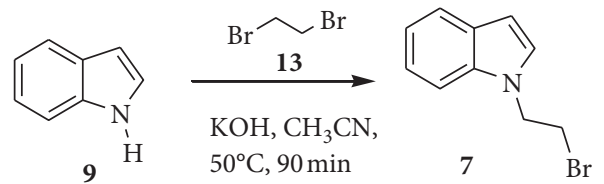

Scheme 3: Synthesis of N-alkylated indole 7.

order to accomplish the synthesis of desired compounds 1-3, we decided to facilitate $\mathrm{O}$-alkylation of benzylic alcohol (4) with readily synthesized $\mathrm{N}$-alkylated indole (7). To our surprise, the $\mathrm{O}$-alkylation reactions reduced the yield and prolonged the reaction time. To overcome this problem, we began to optimize $\mathrm{O}$-alkylation reaction under different conditions, and the results are presented in Table 1.

The O-alkylation between 1-(4-(dimethylamino)phenyl)pentan-1-ol (4) and N-alkylated indole (7) employing $\mathrm{KOH}$ as base under neat conditions resulted traces of O-alkylated product (1) along with the domination of unidentified side reactions (Table 1, entry 1). Screening of various solvents such as pyridine, acetonitrile, and dimethyl formamide provided slightly improved yields of O-alkylated product (1) (entries 3-6). However, substantial amount of starting material was recovered during the course of reaction. Subsequently, it was found that Chi and Kazemi exploited ionic-liquids and phase transfer catalyst in alkylation reaction $[65,66]$. The situation improved dramatically, when we utilized the combination of $\mathrm{K}_{2} \mathrm{CO}_{3}$ / TBAF in acetonitrile to provide the corresponding O-alkylated product (1) with $72 \%$ yield (entry 7 ). Thus, the optimized reaction conditions involved benzylic alcohol (4) (1.5 mmol), $\mathrm{N}$-alkyl indole (7) $(1 \mathrm{mmol}), \mathrm{K}_{2} \mathrm{CO}_{3}(1 \mathrm{mmol})$,
TBAF $(1 \mathrm{mmol})$, and acetonitrile $(10 \mathrm{~mL})$ heated at $50^{\circ} \mathrm{C}$. Under the optimized conditions, we then explored $\mathrm{O}$-alkylation of 1-(4-(dimethylamino)phenyl)propan-1-ol (5) and (4-(dimethylamino)phenyl) (phenyl)methanol (6) with $\mathrm{N}$-alkyl indole (7) to provide the desired compounds 2 and 3 with good yields, respectively.

2.1. In Vitro Antimicrobial Activity. In vitro antifungal activities of the synthesized compounds $\mathbf{1 - 3}$ were evaluated utilizing Staphylococcus aureus and Escherichia coli and antifungal activity against Candida albicans using disc diffusion method (Table 2). The inhibition zone was measured in diameter. Bavistin and chloramphenicol were used as the standard drug to compare antifungal activity. In order to investigate antifungal activity, the inhibition against the test organisms and ethanol as positive control, and the effectiveness of the target compounds (1-3) was measured by calculating inhibition zone against the tested organisms. The zone of inhibition was compared with the standard drug after $72 \mathrm{~h}$. Organisms Staphylococcus aureus (Gram-positive) and Escherichia coli (Gram-negative) were subcultured into sterile nutrient broth. Then, aliquots of $50 \%$ and $100 \%$ of the sample solutions of target compounds, 1-3, were 
TABle 1: Optimization of O-alkylation reaction ${ }^{\mathrm{a}}$.<smiles>CCCCC(O)c1ccc(N(C)C)cc1</smiles>

4

7

\begin{tabular}{|c|c|c|c|c|c|}
\hline Entry & Base (mol\%) & Additives (equiv.) & Solvent $(\mathrm{mL})$ & Temperature $\left({ }^{\circ} \mathrm{C}\right)$ & Yield of $1^{\mathrm{b}, \mathrm{c}}(\%)$ \\
\hline 1 & $\mathrm{KOH}$ & - & Neat & 25 & Traces \\
\hline 2 & Pyridine & - & Pyridine & 80 & $\mathrm{nr}$ \\
\hline 3 & $\mathrm{~K}_{2} \mathrm{CO}_{3}$ & - & $\mathrm{CH}_{3} \mathrm{CN}$ & 80 & 25 \\
\hline 4 & $\mathrm{~K}_{2} \mathrm{CO}_{3}$ & - & DMF & 100 & 20 \\
\hline 5 & $\mathrm{~K}_{2} \mathrm{CO}_{3}(50)$ & TBAF & DMF & 80 & 35 \\
\hline 6 & $\mathrm{~K}_{2} \mathrm{CO}_{3}(50)$ & TBAF (1) & $\mathrm{CH}_{3} \mathrm{CN}$ & 50 & 50 \\
\hline 7 & $\mathrm{~K}_{2} \mathrm{CO}_{3}(100)$ & TBAF (1) & $\mathrm{CH}_{3} \mathrm{CN}$ & 50 & $72^{\mathrm{d}}$ \\
\hline
\end{tabular}

${ }^{a}$ Reaction conditions: alcohol $(1.5 \mathrm{mmol})$, indole-alkyl bromide $(1 \mathrm{mmol})$, base, and solvent; ${ }^{\mathrm{b}}$ isolated yield; ${ }^{\mathrm{c}}$ characterized by IR and NMR; ${ }^{\mathrm{d}}$ further yield did not improve even when the 1.5 equiv. of base was utilized.

TABle 2: Antimicrobial activities of target compound 1-3.

\begin{tabular}{|c|c|c|c|c|c|c|c|}
\hline \multirow{3}{*}{ Sr.No } & \multirow{3}{*}{ Compounds } & \multicolumn{6}{|c|}{ Zone of inhibitions (mm) } \\
\hline & & \multicolumn{2}{|c|}{ Escherichia coli } & \multicolumn{2}{|c|}{ Staphylococcus aureus } & \multicolumn{2}{|c|}{ Candida albicans } \\
\hline & & $50 \%$ & $100 \%$ & $50 \%$ & $100 \%$ & $50 \%$ & $100 \%$ \\
\hline 1 & 1 & - & - & 25 & 27 & - & - \\
\hline \multirow[t]{2}{*}{2} & 2 & - & - & 18 & 20 & - & - \\
\hline & 3 & & & 15 & 20 & & \\
\hline 3 & Chloramphenicol & 2 & 3 & 18 & 20 & - & - \\
\hline 4 & Bavistin & - & - & - & - & 20 & 30 \\
\hline 5 & Negative control & - & - & - & - & - & - \\
\hline
\end{tabular}

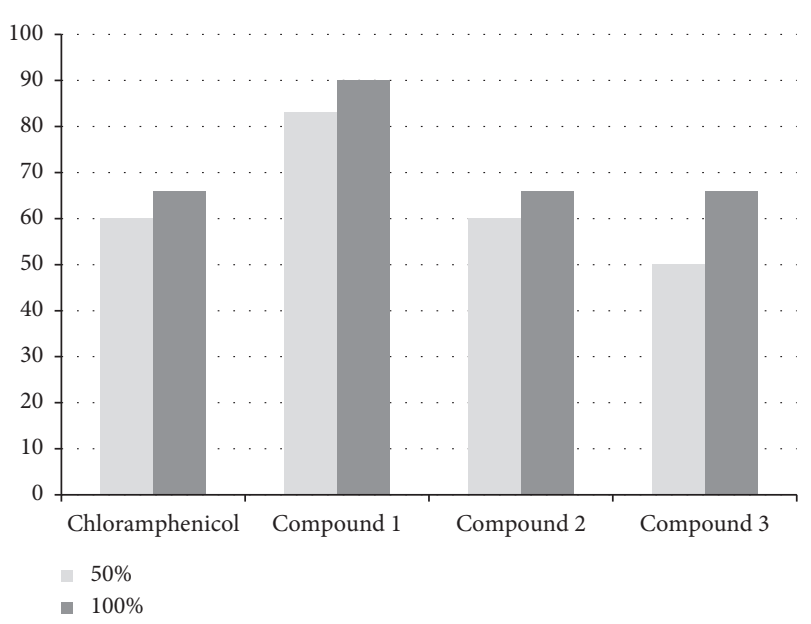

FIgURE 3: Comparison of \% of bioactivity: chloramphenicol drug with compounds 1-3.

pipetted to the discs in three replications each. The discs were impregnated with the sample solutions and then transferred to nutrient agar (NA) plate seeded with bacteria and incubated at $37^{\circ} \mathrm{C}$ for $24 \mathrm{~h}$. Subsequently, the plates were examined for microbial growth of inhibition, and the inhibition zone diameter was measured to the nearest $\mathrm{mm}$. All the tests were performed in triplicate. Obtained bioactivity results were compared with commercially available drugs, chloramphenicol and bavistin, and the results are presented in Figure 3.

\section{Conclusion}

We have reported the synthesis of indole derivatives using commercially available starting materials, and their antimicrobial activity was also investigated. The in vitro bioactivity was performed using Staphylococcus aureus, Escherichia coli, and Candida albicans as antibacterial and antifungal, respectively, using the disc diffusion method. The mean inhibition zone of commercially available drug chloramphenicol and bavistin was used as standard, and inhibition zone was calculated in $\mathrm{mm}$. Compounds 1-3 tested for antifungal and antibacterial activity showed poor inhibition against Gram-negative bacteria Escherichia coli. On the other hand, compounds 1-3 showed good bioactivity towards pathogen Staphylococcus aureus, Gram-positive bacteria. Interestingly, it was observed that compound $\mathbf{1}$, which incorporates butyl substitue nts, exhibited enhanced selectivity compared with analogues 2 and 3. Further 
extension of designing new indole derivatives is currently under development.

\section{Experimental}

4.1. General Experimental Procedure. FTIR spectra of the synthesized compounds were recorded on a Shimadzu 4000 instrument using $\mathrm{KBr}$ pellet within the range of $400 \pm 10$ to $4000 \pm 10 \mathrm{~cm}^{-1}$. ${ }^{1} \mathrm{H}-\mathrm{NMR},{ }^{13} \mathrm{C}-\mathrm{NMR}$, and DEPT- 135 spectra of compounds were recorded on Bruker Avance II- $400 \mathrm{MHz}$ NMR spectrometer in deuterated $\mathrm{CDCl}_{3}, \mathrm{MeOD}$ and DMSO solvents using TMS as internal standard. Chemical shift values are expressed in $\delta(\mathrm{ppm})$.

4.1.1. Pharmacological Reagents. Reagents for biochemical assays such as potato dextrose agar (PDA, Micro master laboratories, India), nutrient agar (NA, Aldrich chemical company, Germany), bavistin (Domina Pharmaceuticals, India), chloramphenicol (Addis Pharmaceuticals S.C., Adigrat, Ethiopia) were used for the antimicrobial studies.

4.2. Synthesis of 1-(4-(dimethylamino)phenyl)pentan-1-ol (4). To an oven-dried three necked round bottom flask, $\mathrm{Mg}$ turnings $(1.25 \mathrm{~g}, 5.14 \mathrm{mmol})$ was charged followed by the addition of iodine crystals (3 piece) and covered the flask with a $\mathrm{CaCl}_{2}$ dry tube. To this, anhydrous diethyl ether $(100 \mathrm{~mL})$ was added using addition funnel. The whole reaction mixture was allowed to stir for 10 minutes. Then, bromobutane $(\mathbf{1 0}) \quad(4.4 \mathrm{~mL}, 4.0 \mathrm{mmol})$ was introduced dropwise with the help of syringe. In order to initiate the reaction, the flask was warmed using hot water, and the addition of bromobutane was continued. It was observed that vigorous reaction between magnesium and bromobutane leads to the formation of Grignard reagent. The Grignard reagent in the flask appears grey in color. To the formed Grignard reagent (BuMgBr), 4-dimethylamino benzaldehyde (8) $(5 \mathrm{~g}, 3.35 \mathrm{mmol})$ dissolved in $50 \mathrm{~mL}$ anhydrous DEE was introduced with the help of an addition funnel (dropwise). After the completion of the reaction $(1 \mathrm{~h})$, which was monitored by TLC, the mixture was quenched with saturated solutions of $\mathrm{NH}_{4} \mathrm{Cl}(20 \mathrm{~mL})$. The resulting mixture was transferred to a separatory funnel followed by the addition of ethyl acetate $(50 \mathrm{~mL})$, and the aqueous layer was removed, and the organic layer was dried with sodium sulphate. The solvent was removed using rotary evaporator, and compound $\mathbf{4}$ was obtained as the crude product. Then, further purification of the residue was performed using column chromatography using $20 \%$ ethyl acetate in petroleum ether as an eluent to give the pure 1-(4-(dimethylamino)phenyl)pentan-1-ol (4).

4.2.1. Appearance. Pale yellow oil yield $=72 \%$ (4.9 g); FT-IR $\left(\mathrm{KBr}, \mathrm{cm}^{-1}\right) .3311(\mathrm{O}-\mathrm{H}$ str), 3072(C-H str, ring/cyclic), 2927(C-H str, acyclic), 1615(C=C str), 1464(C-C str); ${ }^{1} \mathrm{H}-$ NMR ( $\left.\mathrm{CDCl}_{3} / \mathrm{TMS}\right) \delta 0.92\left(t, 3 \mathrm{H},-\mathrm{CH}_{2} \mathrm{CH}_{3}\right), 1.21-1.29(m$, $\left.2 \mathrm{H},-\mathrm{CH}_{2} \mathrm{CH}_{2} \mathrm{CH}_{3}\right), 1.40\left(q, 2 \mathrm{H},-\mathrm{CH}_{2}-\mathrm{CH}-\mathrm{OH}\right), 3.06(s, 6 \mathrm{H}$, $\left.\mathrm{N}-\mathrm{CH}_{3}\right), 4.0(t, 1 \mathrm{H}, \mathrm{OH}), 4.58(t, 1 \mathrm{H}, \mathrm{Ar}-\mathrm{CH}-\mathrm{OH}), 6.76(d$,
1H,Ar-H), 6.76 (d, 1H,Ar-H), 7.25 (d, 1H,Ar-H); ${ }^{13} \mathrm{C}-\mathrm{NMR}$ $\left(\mathrm{CDCl}_{3} / \mathrm{TMS}\right) \delta 76-78\left(\mathrm{CdCl}_{3}\right), \delta 14.09,22.69,28.19,38.47$, $40.78,74.47,112.45,126.97,132.99,150.19$.

4.3. Synthesis of 1-(4-(dimethylamino)phenyl)propan-1-ol (5) via Grignard Reaction. The synthesis 1-(4-(dimethylamino) phenyl)propan-1-ol (5) was also achieved by Grignard reaction. This reaction was carried out similar to the aforementioned process. A $500 \mathrm{~mL}$ oven-dried round bottom flask was charged with $\mathrm{Mg}(1.25 \mathrm{~g}, 51.42 \mathrm{mmol})$ and iodine crystal $(0.2 \mathrm{~g})$ followed by the addition of anhydrous diethyl ether $(100 \mathrm{~mL})$ and stirred for $5 \mathrm{~min}$. To this solution, ethyl iodide (6) (3.23 mL, $40.17 \mathrm{mmol})$ was added slowly with the help of a syringe. Upon addition of ethyl iodide, the reaction mixture color was changed from brown to grey color, which indicates the formation of Grignard reagent. To this Grignard reagent, 4-N,N-dimethylamino benzaldehyde (8) $(5 \mathrm{~g}, 33.51 \mathrm{mmol})$ dissolved in anhydrous DEE was added with the help of the addition funnel. The resulting reaction mixture was stirred at room temperature for $2 \mathrm{~h}$. The reaction was monitored by TLC $20 \%$ of ethyl acetate in petroleum ether. After completion of the reaction, saturated $\mathrm{NH}_{4} \mathrm{Cl}(15 \mathrm{~mL})$ was added to the reaction mixture. The combined organic layers was separated, washed, and dried over anhydrous $\mathrm{Na}_{2} \mathrm{SO}_{4}$. The crude product was obtained by removing organic solvent evaporated using the rotatory evaporator. Furthermore, the purification of crude product was performed using column chromatography: silica gel (100-200 mesh) and 30\% ethyl acetate in petroleum ether as eluents to obtain pure 1-(4-(dimethylamino)phenyl)propan1-ol (5).

Yield (80\%), FR-IR (KBr) stretch(str) $\mathrm{cm}^{-1}: 1522.83$, 1615.41 (str, C=C-Ar), 2873.98 (str, $\left.-\mathrm{CH}_{3}\right), 2930.89$ (str, $-\mathrm{CH}_{2}$ ), 2959.82 (str, $\left.\mathrm{N}\left(\mathrm{CH}_{3}\right)_{2}\right), 3075.55$ (str, C-H), 3096.77, 3141.13 (str C-H-Ar), 3357.16 (str, O-H $)^{1} \mathrm{H}-\mathrm{NMR}$ $\left(400 \mathrm{MHz}, \mathrm{CDCl}_{3}, \mathrm{ppm}\right): \delta=1.01\left(\mathrm{t}, 3 \mathrm{H}, \mathrm{CH}_{3}\right), 1.62-1.96(\mathrm{~m}$, $\left.2 \mathrm{H}, \mathrm{CH}_{2}\right), 2.2(\mathrm{brs}, 1 \mathrm{H}, \mathrm{OH}), 2.84\left(\mathrm{~s}, 6 \mathrm{H}, \mathrm{N}\left(\mathrm{CH}_{3}\right)_{2}\right), 4.63(\mathrm{t}$, $1 \mathrm{H},-\mathrm{CH}), 6.52(\mathrm{~d}, 2 \mathrm{H}, \mathrm{Ar}-\mathrm{H}), 6.97(\mathrm{~d}, 2 \mathrm{H}, \mathrm{Ar}-\mathrm{H}) ;{ }^{13} \mathrm{C}-\mathrm{NMR}$ $\left(100 \mathrm{MHz}, \mathrm{CDCl}_{3}, \mathrm{ppm}\right): \delta=07.87\left(1 \mathrm{C},-\mathrm{CH}_{3}\right), 31.18(1 \mathrm{C}$,$\left.\mathrm{CH}_{2}\right), 40.67\left(2 \mathrm{C}, \mathrm{N}\left(\mathrm{CH}_{3}\right)_{2}\right), 79.32(1 \mathrm{C},-\mathrm{C}-\mathrm{OH}), 114.87(2 \mathrm{C}$, Ar-C), 128.11 (2C, Ar-C), 129.17 (1C,Ar-C), 146.12 (1C, ArC).

4.4. Synthesis of (4-(dimethyl Amino) Phenyl) (Phenyl) Methanol (6). To a three-necked round bottom flask, ovendried $\mathrm{Mg} 1.17 \mathrm{~g}(4.87 \mathrm{mmol})$ and few crystals of iodine were taken and maintained inert atmosphere. To this flask, anhydrous diethyl ether $(100 \mathrm{~mL})$ was added with continuous stirring. The solution turned into brown color, and the flask was warmed using hot water. Then, bromobenzene (12) $(6.5 \mathrm{~mL}, 6.2 \mathrm{mmol})$ was added dropwise maintaining the flask in ice cold water while the addition of bromobenzene was continued. The color of the reaction mixture turned to grey due to the formation of Grignard reagent phenyl magnesium bromide ( $\mathrm{PhMgBr}$ ). To this reaction mixture, 4dimethylamino benzaldehyde (8) $(5 \mathrm{~g}, 3.35 \mathrm{mmol})$ dissolved in $40 \mathrm{~mL}$ of anhydrous DEE was added drop wise. After completion of reaction, which was monitored by TLC, the 
reaction mixture was quenched with saturated solution of ammonium chloride $(20 \mathrm{~mL})$. The resulting organic layer was then transferred to the separatory funnel, and the collected organic layer was dried over sodium sulphate. The solvent was removed using rotary evaporator, and the crude residue was further purified by column chromatography. The column chromatography was performed using $20 \%$ ethyl acetate in petroleum ether as the eluent to give pure (4(dimethyl amino) phenyl) (phenyl) methanol in 67\% yield $(5.15 \mathrm{~g})$ as a pale yellow solid.

FT-IR $\left(\mathrm{KBr}, \mathrm{cm}^{-1}\right)$ : 3454(O-H str), 2923-2955(C-H str), 1615(C $=\mathrm{C}$ str); ${ }^{1} \mathrm{H}-\mathrm{NMR}\left(\mathrm{CDCl}_{3} / \mathrm{TMS}\right): \delta 2.90(s, 6 \mathrm{H}$, $\left.\mathrm{N}-\mathrm{CH}_{3}\right), 5.72\left(s, 1 \mathrm{H},(\mathrm{Ar})_{2}-\mathrm{CH}-\mathrm{OH}\right), 6.67(d, 1 \mathrm{H}, \mathrm{OH})$, 7.16-7.38 (d, Ar-H); ${ }^{13} \mathrm{C}-\mathrm{NMR}\left(\mathrm{CDCl}_{3} / \mathrm{TMS}\right): \delta 40.12,79.67$, 114.22 , 125.87, 129.12, 129.82, 130.11, 130.80, 131.13, 140.06, 146.67.

4.5. Synthesis of 1-(2-bromoethyl)-1H-indole (7). A $100 \mathrm{~mL}$ round bottom flask was charged with potassium hydroxide $(3.83 \mathrm{~g}, 68.3 \mathrm{mmol})$ and tetrabutylammonium fluoride $(0.14 \mathrm{~g}, 0.54 \mathrm{mmol})$. Then, indole (9) $(2 \mathrm{~g}, 17.1 \mathrm{mmol})$, which was dissolved in anhydrous DMF $(25 \mathrm{~mL})$, was added slowly to the above mixture with stirring. Then, the reaction mixture was heated at $50 \mathrm{C}$ for $1.5 \mathrm{~h}$ and then cooled to $0 \mathrm{C}$. To this cooled reaction mixture 1,2-dibromoethane (10) $(1.5 \mathrm{~mL}, 17.1 \mathrm{mmol})$ was added slowly with the help of syringe. Furthermore, the reaction mixture was allowed to stir for $30 \mathrm{~min}$ at $0 \mathrm{C}$ and again heated at $50 \mathrm{C}$ for $2 \mathrm{~h}$. The reaction was monitored by TLC. After completion of reaction, the reaction mixture was poured in $70 \mathrm{~mL}$ water and extracted with dichloromethane $(3 \times 50 \mathrm{~mL})$. The combined organic layers were washed with brine, and collected organic layers were dried over sodium sulphate. The solvent was removed using rotary evaporator, and the crude residue was subjected to column chromatography. The column chromatography was performed using silica gel and eluent combinations of petroleum ether/ethyl acetate $(9: 1)$ to obtain pure 1-(2-bromoethyl)-1H-indole in 54\% yield ( $2.3 \mathrm{~g}$ ) as pale yellow oil.

$\left.{ }^{1} \mathrm{H}-\mathrm{NMR}\left(\mathrm{CDCl}_{3}+\mathrm{MeOD}\right) / \mathrm{TMS}\right): \delta 3.33\left(t, 2 \mathrm{H},-\mathrm{CH}_{2^{-}}\right.$ $\mathrm{Br}), 4.31\left(t, 2 \mathrm{H}, \mathrm{N}-\mathrm{CH}_{2}-\right), 6.61(d, 1 \mathrm{H}$, pyrrole $-\mathrm{H}), 7.12(d$, $1 \mathrm{H}$, benzene $-\mathrm{H}), 7.23(d, 1 \mathrm{H}$, pyrrole $-\mathrm{H}), 7.45(t, 1 \mathrm{H}$, benzene - H), $7.60(d, 1 \mathrm{H}$, benzene - $\mathrm{H}) ;{ }^{13} \mathrm{C}-\mathrm{NMR}$ $\left.\left(\mathrm{CDCl}_{3}+\mathrm{MeOD}\right) / \mathrm{TMS}\right): \delta 80.9\left(\mathrm{CDCl}_{3}\right), 52.6(\mathrm{MeOD}), 25.4$, $100.2,108.7,113.4,124.5,126.5,127.2,133.5,139.4,139.6$.

4.6. Synthesis of 4-(1-(2-(1H-indol-1-yl) Ethoxy) pentyl)-N,Ndimethyl Aniline (1). A compound 1 was synthesized using $O$-alkylation reaction by combining intermediate 4 with 7 . To a round bottom flask Grignard product, secondary alcohol (4) $(0.31 \mathrm{~g}, 1.5 \mathrm{mmol})$ was charged followed by the addition of phase transfer catalyst TBAF $(0.31,1.0 \mathrm{mmol})$ and acetonitrile $(10 \mathrm{~mL})$. This reaction mixture was stirred at room temperature, and then $\mathrm{K}_{2} \mathrm{CO}_{3}(0.14 \mathrm{~g}, 1 \mathrm{mmol})$ was added slowly and allowed whole reaction mixture to heat at $50 \mathrm{C}$. To this hot reaction mixture, $\mathrm{N}$-alkylated product 1-(2bromoethyl)- $1 \mathrm{H}$-indole (7) $(0.224 \mathrm{~g}, 1 \mathrm{mmol})$ was added slowly. The reaction mixture was stirred further, and the progress of the reaction was monitored by TLC. After cooling the reaction mixture at room temperature, the reaction mixture was poured in $30 \mathrm{~mL}$ water and then extracted with $50 \mathrm{~mL}$ ethyl acetate. The combined organic layers were dried over anhydrous $\mathrm{Na}_{2} \mathrm{SO}_{4}$, and the solvent was removed using rotary evaporator.

The residue was purified by column chromatography and air pressure using a $1: 12(\mathrm{v} / \mathrm{v})$ mixture of ethyl acetate and petroleum ether as eluting solution to afford 4-(1-(2(1H-indol-1-yl) ethoxy) pentyl)-N, N-dimethyl aniline (1) in $72 \%$ yield $(0.28 \mathrm{~g})$ as yellow color oil.

${ }^{1} \mathrm{H}-\mathrm{NMR}$ (DMSO/TMS): $\delta 1.30\left(t, 3 \mathrm{H},-\mathrm{CH}_{2} \mathrm{CH}_{3}\right)$, 1.65-1.81 ( $\left.m, 4 \mathrm{H},-\mathrm{CH}_{3} \mathrm{CH}_{2} \mathrm{CH}_{2^{-}}\right), 2.50\left(t, 2 \mathrm{H}, \mathrm{O}-\mathrm{CH}-\mathrm{CH}_{2}-\right.$ ), $3.14\left(s, 6 \mathrm{H},-\mathrm{N}-\left(\mathrm{CH}_{3}\right)_{2}\right), 4.76\left(t, 2 \mathrm{H}, \mathrm{O}-\mathrm{CH}_{2}-\right), 4.94(t, 2 \mathrm{H}$, $\left.\mathrm{N}-\mathrm{CH}_{2}-\right), 5.36(t, 1 \mathrm{H},-\mathrm{O}-\mathrm{CH}-\mathrm{Ar}), 6.37$ (d, $1 \mathrm{H}$, ,pyrrole), 6.62 $(d, 1,1 \mathrm{H}, \mathrm{Ph} .-\mathrm{H}), 6.62(d, 1 \mathrm{H}, \mathrm{Ar}-\mathrm{H}), 6.95,(\mathrm{t}, 1 \mathrm{H}, \mathrm{Ar}-\mathrm{H})$, $7.39(\mathrm{~d}, 1 \mathrm{H}, \mathrm{Ph}-\mathrm{H}), 7.46(d, 1 \mathrm{H}$, pyrrole), $7.54(t, 1 \mathrm{H}, \mathrm{Ar}-\mathrm{H})$, $7.62(d, \mathrm{Ar}-\mathrm{H}, 1 \mathrm{H}), 7.89(d, 1 \mathrm{H}, \mathrm{Ar}-\mathrm{H}) ;{ }^{13} \mathrm{C}-\mathrm{NMR}$ (DMSO/ TMS): $\delta 14.19,23.27,28.59,35.62,39.03,40.80,74.53,77.68$, $96.38,105.29,109.80,113.01,121.08,121.43,122.99,127.15$, 129.86, 130.22, 133.61, 149.93 .

4.7. Synthesis of 4-((2-(1H-indol-1-yl) Ethoxy) (Phenyl) methyl)-N,N-dimethyl Aniline (2). The synthesis of target compound $\mathbf{2}$ was carried out by using the same procedure and conditions, which was described for the synthesis of compound 1. To a round bottom flask Grignard product, secondary alcohol $\mathbf{6}(0.34 \mathrm{~g}, 1.5 \mathrm{mmol})$ was charged followed by the addition of phase transfer catalyst TBAF $(0.316$, $1.0 \mathrm{mmol})$ and acetonitrile $(10 \mathrm{~mL})$. The reaction mixture was stirred at room temperature, and then $\mathrm{K}_{2} \mathrm{CO}_{3}(0.14 \mathrm{~g}$, $1 \mathrm{mmol}$ ) was added slowly and allowed whole reaction mixture to heat at $50^{\circ} \mathrm{C}$. To this hot reaction mixture, $\mathrm{N}$-alkylated product 1-(2-bromoethyl)-1H-indole (7) $(0.224 \mathrm{~g}, 1.0 \mathrm{mmol})$ was added slowly. The reaction mixture was stirred further, and the progress of the reaction was monitored by TLC. After cooling the reaction mixture at room temperature, the reaction mixture was poured in $30 \mathrm{~mL}$ water and then extracted with $50 \mathrm{~mL}$ ethyl acetate. The combined organic layers were dried over anhydrous $\mathrm{Na}_{2} \mathrm{SO}_{4}$, and the solvent was removed using rotary evaporator. The residue was purified by column chromatography with air pressure using a $1: 12(\mathrm{v} / \mathrm{v})$ mixture of ethyl acetate and petroleum ether as eluent to afford $4-((2-21 \mathrm{H}$-indol-1yl) ethoxy) (phenyl) methyl)-N, N-dimethyl aniline (2) in $64 \%$ yield $(0.25 \mathrm{~g})$.

${ }^{1} \mathrm{H}-\mathrm{NMR}$ (DMSO/TMS): $\delta 2.95$ (d, 6H, -N- $\left.\left(\mathrm{CH}_{3}\right)_{2}\right), 4.63$ $\left(t, 2 \mathrm{H},-\mathrm{O}-\mathrm{CH}_{2}-\right), 5.07\left(t, 2 \mathrm{H},-\mathrm{N}-\mathrm{CH}_{2}\right), 5.66(s, 1 \mathrm{H},-\mathrm{O}-\mathrm{CH}-)$, $6.54(d, 1 \mathrm{H}, \operatorname{Ar}-\mathrm{H}), 7.13(t, 1 \mathrm{H}, \operatorname{Ar}-\mathrm{H}), 7.28(d, 1 \mathrm{H}, \operatorname{Ar}-\mathrm{H})$, $7.32(d, 1 \mathrm{H}$, pyrrole), $7.60(t, 1 \mathrm{H}, \mathrm{Ar}-\mathrm{H}), 7.68(d, 1 \mathrm{H}, \mathrm{Ar}-\mathrm{H})$; ${ }^{13} \mathrm{C}$-NMR (DMSO/TMS): $\delta \quad 40.59,58.21,96.48,109.54$, $110.52,112.41,120.71,121.05,123.42,126.54,127.73,128.04$, $129.30,131.20,132.66,135.38,139.23,145.71,149.73,153.36$.

4.8. Synthesis of 4-((2-(1H-indol-1-yl) Ethoxy) (Phenyl) methyl)-N,N-dimethyl Aniline (3). The synthesis of target compound $\mathbf{3}$ was carried out by using same procedure and 
conditions, which was described for the synthesis of compound $\mathbf{1}$.

The synthesis of target compound $\mathbf{2}$ was carried out by using same procedure and conditions, which was described for the synthesis of compound $\mathbf{1}$. To a round bottom flask Grignard product, secondary alcohol $5(0.34 \mathrm{~g}, 1.5 \mathrm{mmol})$ was charged followed by the addition of phase transfer catalyst TBAF $(0.316,1.0 \mathrm{mmol})$ and acetonitrile $(10 \mathrm{~mL})$. The reaction mixture was stirred at room temperature, and then $\mathrm{K}_{2} \mathrm{CO}_{3}(0.14 \mathrm{~g}, 1 \mathrm{mmol})$ was added slowly and allowed whole reaction mixture to heat at $50^{\circ} \mathrm{C}$. To this hot reaction mixture, N-alkylated product 1-(2-bromoethyl)-1H-indole (3) $(0.224 \mathrm{~g}, 1.0 \mathrm{mmol})$ was added slowly. The reaction mixture was stirred further, and the progress of the reaction was monitored by TLC. After cooling the reaction mixture at room temperature, the reaction mixture was poured in $30 \mathrm{~mL}$ water and then extracted with $50 \mathrm{~mL}$ ethyl acetate. The combined organic layers were dried over anhydrous $\mathrm{Na}_{2} \mathrm{SO}_{4}$, and the solvent was removed using rotary evaporator. The residue was purified by column chromatography with air pressure using a 1:12 (v/v) mixture of ethyl acetate and petroleum ether as eluent to afford 4-((2-(1H-indol-1-yl) ethoxy) (phenyl) methyl)-N, $\mathrm{N}$-dimethyl aniline (2) in $64 \%$ yield $(0.25 \mathrm{~g})$.

${ }^{1} \mathrm{H}-\mathrm{NMR}$ (DMSO/TMS): $\delta 2.95$ (d, 6H, - N- $\left.\left(\mathrm{CH}_{3}\right)_{2}\right), 4.63$ $\left(t, 2 \mathrm{H},-\mathrm{O}-\mathrm{CH}_{2}-\right), 5.07\left(t, 2 \mathrm{H},-\mathrm{N}-\mathrm{CH}_{2}\right), 5.66(s, 1 \mathrm{H},-\mathrm{O}-\mathrm{CH}-)$, $6.54(d, 1 \mathrm{H}, \mathrm{Ar}-\mathrm{H}), 7.13(t, 1 \mathrm{H}, \mathrm{Ar}-\mathrm{H}), 7.28(d, 1 \mathrm{H}, \mathrm{Ar}-\mathrm{H})$, $7.32(d, 1 \mathrm{H}$, pyrrole), $7.60(t, 1 \mathrm{H}, \mathrm{Ar}-\mathrm{H}), 7.68(d, 1 \mathrm{H}, \mathrm{Ar}-\mathrm{H})$; ${ }^{13}$ C-NMR (DMSO/TMS): $\delta 40.59,58.21,96.48,109.54$, $110.52,112.41,120.71,121.05,123.42,126.54,127.73,128.04$, $129.30,131.20,132.66,135.38,139.23,145.71,149.73,153.36$.

\section{Data Availability}

The data used to support the findings of this study are available from the corresponding author upon request.

\section{Conflicts of Interest}

The authors declare that they have no conflicts of interest.

\section{Acknowledgments}

This work was supported by the PG Research grant of Mekelle University. The authors are thankful to Department of Chemistry and College of Natural and Computation Science for providing research facilities to complete this work.

\section{Supplementary Materials}

This section includes FT-IR spectrum, 1H-NMR spectrum, 13C-NMR spectrum, and DEPT-135 spectrum of 1-(4(dimethylamino)phenyl)pentan-1-ol (4); FT-IR spectrum and 1H-NMR spectrum of (4-(dimethyl amino)phenyl)(phenyl) methanol (6); 1H-NMR spectrum of and 13C-NMR spectrum of 1-(2-bromoethyl)-1H-indole (6); 1H-NMR spectrum, 13C-NMR spectrum, and DEPT-135 spectrum of 4-(1-(2-(1H-indol-1-yl)ethoxy) pentyl)-N,N-dimethyl aniline (1); $1 \mathrm{H}-\mathrm{NMR}$ spectrum and 13C-NMR spectrum of 4-
((2-(1H-indol-1-yl)ethoxy) (phenyl) methyl)-N,N-dimethyl aniline (3). (Supplementary Materials)

\section{References}

[1] A. R. Katritzky and C. W. Rees, Eds., Comprehensive Heterocyclic Chemistry, Pergamon, Vol. 1, Oxford, UK, 1984.

[2] A. F. Pozharskii, A. T. Soldatenkov, and A. R. Katritzky, Heterocycles in Life and Society: An Introduction to Heterocyclic Chemistry, Biochemistry and Applications, Wiley, Hoboken, NJ, USA, 2nd edition, 2011.

[3] J. N. R. Delgado, Wilson and Giswold's- Textbook of Organic Chemistry Medicinal and Pharmaceutical Chemistry, Lippincott Raven, Philadelphia, PA, USA, 10th edition, 1998.

[4] E. Vitaku, D. T. Smith, and J. T. Njardarson, "Analysis of the structural diversity, substitution patterns, and frequency of nitrogen heterocycles among U.S. FDA approved pharmaceuticals," Journal of Medicinal Chemistry, vol. 57, no. 24, pp. 10257-10274, 2014.

[5] J. A. Joule and K. Mills, Heterocyclic Chemistry, Blackwell Science, Oxford, UK, 2000.

[6] T. Eicher, S. Hauptmann, and A. Speicher, The Chemistry of Heterocycles, Wiley-VCH Verlag GmbH \& Co., Weinheim, Germany, 2nd edition, 2003.

[7] K. C. Nicolaou and J. S. Chen, "Total synthesis of complex heterocyclic natural products," Pure and Applied Chemistry, vol. 80, no. 4, pp. 727-742, 2008.

[8] E. A. Mitchell, A. Peschiulli, N. Lefevre, L. Meerpoel, and B. U. W. Maes, "Direct $\alpha$-functionalization of saturated cyclic amines," Chemistry - A European Journal, vol. 18, no. 33, pp. 10092-10142, 2012.

[9] C.-V. T. Vo and J. W. Bode, "Synthesis of saturated N-heterocycles," The Journal of Organic Chemistry, vol. 79, no. 7, pp. 2809-2815, 2014.

[10] A. Gomtsyan, "Heterocycles in drugs and drug discovery," Chemistry of Heterocyclic Compounds, vol. 48, pp. 7-10, 2012.

[11] A. T. Balaban, D. C. Oniciu, and A. R. Katritzky, "Aromaticity as a cornerstone of heterocyclic chemistry," Chemical Reviews, vol. 104, no. 5, pp. 2777-2812, 2004.

[12] R. E. Dolle and K. H. Nelson, "Comprehensive survey of combinatorial library synthesis: 1998," Journal of Combinatorial Chemistry, vol. 1, no. 4, pp. 235-282, 1999.

[13] H.-J. Knölker and K. R. Reddy, "Isolation and synthesis of biologically active carbazole alkaloids," Chemical Reviews, vol. 102, no. 11, pp. 4303-4428, 2002.

[14] S. Bähn, S. Imm, K. Mevius et al., "Selective rutheniumcatalyzed N-alkylation of indoles by using alcohols," Chemistry-A European Journal, vol. 16, no. 12, pp. 3590-3593, 2010.

[15] T. V. Sravanthi and S. L. Manju, "Indoles-a promising scaffold for drug development," European Journal of Pharmaceutical Sciences, vol. 91, pp. 1-10, 2016.

[16] N. Kaushik, N. Kaushik, P. Attri et al., "Biomedical importance of indoles," Molecules, vol. 18, no. 6, pp. 6620-6662, 2013.

[17] M.-Z. Zhang, Q. Chen, and G.-F. Yang, "A review on recent developments of indole-containing antiviral agents," European Journal of Medicinal Chemistry, vol. 89, pp. 421-441, 2015.

[18] M. T. Rahman, J. R. Deschamps, G. H. Imler, and J. M. Cook, "Total synthesis of sarpagine-related bioactive indole alkaloids," Chemistry-A European Journal, vol. 24, no. 10, pp. 2354-2359, 2018. 
[19] S. Lal and T. J. Snape, "2-arylindoles: a privileged molecular scaffold with potent, broad-ranging pharmacological activity," Current Medicinal Chemistry, vol. 19, no. 28, pp. 4828-4837, 2012.

[20] V. Sharma, K. Pradeep, and P. Devender, "Biological importance of the indole nucleus in recent years: a comprehensive review," Journal of Heterocyclic Chemistry, vol. 47, pp. 491-502, 2010.

[21] P. Martins, J. Jesus, S. Santos et al., "Heterocyclic anticancer compounds: recent advances and the paradigm shift towards the use of nanomedicine's tool box," Molecules, vol. 20, no. 9, pp. 16852-16891, 2015.

[22] Top Prescription Drugs by U.S. Sales 2014 |Statistic, http:// www.statista.com/statistics/258010/top-branded-drugs-basedon-retail-sales-in-the-us/.

[23] J. E. Saxton, "Monoterpenoid indole alkaloids," in The Chemistry of Heterocyclic Compounds Part 4, John Wiley \& Sons, Hoboken, NJ, USA, 2008.

[24] B. V. S. Reddy, A. Venkata Ganesh, M. Vani, T. Ramalinga Murthy, S. V. Kalivendi, and J. S. Yadav, "Thee-component, one-pot synthesis of hexahydroazepino[3,4- b]indole and tetrahydro-1 $\mathrm{H}$-pyrido[3,4- b]indole derivatives and evaluation of their cytotoxicity," Bioorganic \& Medicinal Chemistry Letters, vol. 24, no. 18, pp. 4501-4503, 2014.

[25] R. Gali, J. Banothu, R. Gondru, R. Bavantula, Y. Velivela, and P. A. Crooks, "One-pot multicomponent synthesis of indole incorporated thiazolylcoumarins and their antibacterial, anticancer and DNA cleavage studies," Bioorganic \& Medicinal Chemistry Letters, vol. 25, no. 1, pp. 106-112, 2015.

[26] G. A. Khan, J. A. War, A. Kumar, I. A. Sheikh, A. Saxena, and R. Das, "A facile synthesis of novel indole derivatives as potential antitubercular agents," Journal of Taibah University for Science, vol. 11, no. 6, pp. 910-921, 2017.

[27] I. Andreadou, A. Tasouli, E. Chrysselisfilis et al., "Antioxidant activity of novel indole derivatives and protection of the myocardial damage in rabbits," Chemical \& Pharmaceutical Bulletin, vol. 50, no. 2, pp. 165-168, 2002.

[28] M. M. Sayed, Y. M. Moustafa, and A. N. Mohamed, "Novel indolyl-pyrimidine derivatives: synthesis, antimicrobial and antioxidant evaluations," Medicinal Chemistry Research, vol. 23, no. 7, pp. 3374-3388, 2014.

[29] H. Abdel-Gawad, H. A. Mohamed, K. M. Dawood, and F. A.-R. Badria, "Synthesis and antiviral activity of new indole-based heterocycles," Chemical \& Pharmaceutical Bulletin, vol. 58, no. 11, pp. 1529-1531, 2010.

[30] W. Hu, Z. Guo, X. Yi, C. Guo, F. Chu, and G. Cheng, "Discovery of 2-phenyl-3-sulfonylphenyl-indole derivatives as a new class of selective COX-2 inhibitors," Bioorganic \& Medicinal Chemistry, vol. 11, no. 24, pp. 5539-5544, 2003.

[31] R. P. Srivastava and V. K. Kumar, "Synthesis and anti-inflammatory activity of heterocyclic indole derivatives," $\mathrm{Eu}$ ropean Journal of Medicinal Chemistry, vol. 39, no. 5, pp. 449-452, 2004.

[32] B. Narayana, B. V. Ashalatha, K. K. Vijaya Raj, J. Fernandes, and B. K. Sarojini, "Synthesis of some new biologically active 1,3,4-oxadiazolyl nitroindoles and a modified Fischer indole synthesis of ethyl nitro indole-2-carboxylatesfied Fischer indole synthesis of ethyl nitro indole-2-carboxylates," Bioorganic \& Medicinal Chemistry, vol. 13, no. 15, pp. 4638-4644, 2005.

[33] S. D. Kuduk, R. K. Chang, J. M.-C. Wai et al., "Amidine derived inhibitors of acid-sensing ion channel-3 (ASIC3)," Bioorganic \& Medicinal Chemistry Letters, vol. 19, no. 15, pp. 4059-4063, 2009.
[34] D. S. Donawade, A. V. Raghu, and G. S. Gadaginamath, "Synthesis and antimicrobial activ-ity of new 1-substituted-3pyrrolyl aminocarbonyl/oxadiazolyl/triazolyl/5-methoxy-2methylindoles and benz[g]indoles," Indian Journal of Chemistry B, vol. 45, no. 3, pp. 689-696, 2006.

[35] Y. M. A. Hiari, A. M. Qaisi, M. M. Abadelah, and W. Voelter, "Synthesis and antibacterial activity of some substituted 3(aryl)- and 3-(hete roaryl)indoles," Monatshefte für Chemie-Chemical Monthly, vol. 137, no. 2, pp. 243-248, 2006.

[36] M.-Z. Zhang, N. Mulholland, D. Beattie et al., "Synthesis and antifungal activity of 3-(1,3,4-oxadiazol-5-yl)-indoles and 3(1,3,4-oxadiazol-5-yl)methyl-indoles," European Journal of Medicinal Chemistry, vol. 63, pp. 22-32, 2013.

[37] S. A. Patil, R. Patil, and D. D. Miller, "Indole molecules as inhibitors of tubulin polymerization: potential new anticancer agents," Future Medicinal Chemistry, vol. 4, no. 16, pp. 2085-2115, 2012.

[38] E. G. Rogan, "The natural chemopreventive compound indole-3-carbinol: state of the science," In Vivo, vol. 20, pp. 221-228, 2006.

[39] B. Biersack and R. Schobert, "Indole compounds against breast cancer: recent developments," Current Drug Targets, vol. 13, no. 14, pp. 1705-1719, 2012.

[40] J. Badiger, K. Manjulatha, M. Girish, A. Sharif, and M. G. Purohit, "Synthesis and biological evaluation of some N-substituted indole analogues," Arkivoc, vol. 12, pp. 217-231, 2009.

[41] R. Gastpar, M. Goldbrunner, D. Marko, and E. von Angerer, "Methoxy-substituted 3-formyl-2-phenylindoles inhibit tubulin polymerization," Journal of Medicinal Chemistry, vol. 41, no. 25, pp. 4965-4972, 1998.

[42] J. A. Campbell, V. Bordunov, C. A. Broka et al., "Preparation of 3-arylmethylindoles as selective COX-2 inhibitors," Tetrahedron Letters, vol. 45, no. 19, pp. 3793-3796, 2004.

[43] M. Chen, C.-L. Shao, X.-M. Fu et al., "Bioactive indole alkaloids and phenyl Ether derivatives from a marine-derived aspergillus sp. Fungus," Journal of Natural Products, vol. 76, no. 4, pp. 547-553, 2013.

[44] S. Roy, A. Eastman, and G. W. Gribble, "Synthesis of bisindolylmaleimides related to GF109203x and their efficient conversion to the bioactive indolocarbazoles," Organic \& Biomolecular Chemistry, vol. 4, no. 17, pp. 3228-3234, 2006.

[45] C. P. Gordon, B. Venn-Brown, M. J. Robertson et al., "Development of second-generation indole-based dynamin GTPase inhibitors," Journal of Medicinal Chemistry, vol. 56, no. 1, pp. 46-59, 2013.

[46] R. Pereira, R. Benedetti, S. Pérez-Rodríguez et al., "Indolederived psammaplin A analogues as epigenetic modulators with multiple inhibitory activities," Journal of Medicinal Chemistry, vol. 55, no. 22, pp. 9467-9491, 2012.

[47] Z. Liu, L. Tang, H. Zhu et al., "Design, synthesis, and structure-activity relationship study of novel indole-2-carboxamide derivatives as anti-inflammatory agents for the treatment of sepsis," Journal of Medicinal Chemistry, vol. 59, no. 10, pp. 4637-4650, 2016.

[48] E. R. El-Sawy, M. S. Ebaid, H. M. Abo-Salem, A. G. Al-Sehemi, and A. H. Mandour, "Synthesis, anti-inflammatory, analgesic and anticonvulsant activities of some new 4,6-dimethoxy-5(heterocycles)benzofuran starting from naturally occurring visnagin," Arabian Journal of Chemistry, vol. 7, no. 6, pp. 914-923, 2013.

[49] X. Cao, Z. Sun, Y. Cao et al., "Design, synthesis, and structureactivity relationship studies of novel fused heterocycles-linked 
triazoles with good activity and water solubility," Journal of Medicinal Chemistry, vol. 57, no. 9, pp. 3687-3706, 2014.

[50] Y. Chen, K. Yu, N.-Y. Tan et al., "Synthesis, characterization and anti-proliferative activity of heterocyclic hypervalent organoantimony compounds," European Journal of Medicinal Chemistry, vol. 79, pp. 391-398, 2014.

[51] S. Biswal, U. Sahoo, S. Sethy, H. K. S. Kumar, and M. Banerjee, "Indole: the molecule of diverse biological activities," Asian Journal of Pharmaceutical \& Clinical Research, vol. 5, pp. 1-6, 2012.

[52] G. R. Humphrey and J. T. Kuethe, "Practical methodologies for the synthesis of indoles," Chemical Reviews, vol. 106, no. 7, pp. 2875-2911, 2006.

[53] M. D. Remington, The Science and Practice of Pharmacy, Vol. 425, MACK Publishing Company, London, UK, 19th edition, 1995.

[54] S. Kumar, S. Mehndiratta, K. Nepali et al., "Novel indolebearing combretastatin analogues as tubulin polymerization inhibitors," Organic and Medicinal Chemistry Letters, vol. 3, no. 1, pp. 3-13, 2013.

[55] M. Bandini and A. Eichholzer, "Catalytic functionalization of indoles in a new dimension," Angewandte Chemie International Edition, vol. 48, no. 51, pp. 9608-9644, 2009.

[56] S. Cacchi and G. Fabrizi, "Synthesis and functionalization of indoles through palladium-catalyzed reactionst," Chemical Reviews, vol. 105, no. 7, pp. 2873-2920, 2005.

[57] G. Zeni and R. C. Larock, "Synthesis of heterocycles via palladium $\pi$-olefin and $\pi$-alkyne chemistry," Chemical Reviews, vol. 104, no. 5, pp. 2285-2310, 2004.

[58] N. T. Patil and Y. Yamamoto, "Coinage metal-assisted synthesis of heterocycles," Chemical Reviews, vol. 108, no. 8, pp. 3395-3442, 2008.

[59] J. A. Joule, Science of Synthesis (Houben-Weyl Methods of Molecular Transformations), Chapter 10, Thieme Verlag, vol. 10, p. 13, Stuttgart, Germany, 2000.

[60] L. Ling, J. Cao, J. Hu, and H. Zhang, "Copper-catalyzed $\mathrm{N}$-alkylation of indoles by N-tosylhydrazones," RSC Advances, vol. 7, no. 45, pp. 27974-27980, 2017.

[61] A. H. Magdy, Zahran, and A. M. Ibrahim, "Synthesis and cellular cytotoxicities of new $\mathrm{N}$ - substituted indole-3-carbaldehyde and their indolylchalcones," Journal of Chemical Science, vol. 121, pp. 455-462, 2009.

[62] W. Tejchman, I. Korona-Glowniak, A. Malm, M. Zylewski, and P. Suder, "Antibacterial properties of 5-substituted derivatives of rhodanine-3-carboxyalkyl acids," Medicinal Chemistry Research, vol. 26, no. 6, pp. 1316-1324, 2017.

[63] F. Lelario, L. Scrano, S. De Franchi et al., "Identification and antimicrobial activity of most representative secondary metabolites from different plant species," Chemical \& Biological Technologies in Agriculture, vol. 5, pp. 1-12, 2018.

[64] C. Mésangeau, E. Amata, W. Alsharif et al., "Synthesis and pharmacological evaluation of indole-based sigma receptor ligands," European Journal of Medicinal Chemistry, vol. 46, no. 10, pp. 5154-5161, 2011.

[65] Y. R. Jorapur, J. M. Jeong, and D. Y. Chi, "Potassium carbonate as a base for the $\mathrm{N}$-alkylation of indole and pyrrole in ionic liquids," Tetrahedron Letters, vol. 47, no. 14, pp. 2435-2438, 2006.

[66] M. Kazemia, Z. Noorib, H. Kohzadia, M. Sayadia, and A. Kazemia, "A mild and efficient procedure for the synthesis of ethers from various alkyl halides," Iranian Chemical Communication, vol. 1, pp. 43-50, 2013.
[67] T. Eicher, S. Hauptmann, and A. Speicher, The Chemistry of Heterocycles, Wiley-VCH Verlag GmbH \& Co., Weinheim, Germany, 2nd edition, 2003. 